\title{
Countering the Pedagogy of Extremism: Reflective Narratives and Critiques of Problem-Based Learning
}

\author{
Chris W. H. Woo ${ }^{1} \&$ Kumar Laxman ${ }^{2}$ \\ ${ }^{1}$ Faculty of Arts and Social Sciences, Universiti Brunei Darussalam, Brunei Darussalam \\ ${ }^{2}$ School of Curriculum and Pedagogy, The University of Auckland, New Zealand \\ Correspondence: Chris W. H. Woo, Professional Communication and Media Programme, Faculty of Arts and \\ Social Science, Universiti Brunei Darussalam, Jalan Tunku Link, Gadong, Brunei-Muara, BE1410, Brunei \\ Darussalam. Tel: 673-814-2880. E-mail: chris.woo@ubd.edu.bn
}

Received: October 4, 2012 Accepted: November 8, 2012 Online Published: November 20, 2012

doi:10.5539/ies.v6n1p46 URL: http://dx.doi.org/10.5539/ies.v6n1p46

\begin{abstract}
This paper is a critique against "purist" pedagogies found in the literature of student-centred learning. The article reproves extremism in education and questions the absolutism and teleological truths expounded in exclusive problem-based learning. The paper articulates the framework of a unifying pedagogical practice through Eve Kosofsky Sedgwick's conceptual use of beside and leverages upon translation theory to counter argue against a pedagogy of extremism. The teaching and learning narratives of the authors are invoked in critiquing student-centred learning approaches that attempt to minimize the authority of the teacher/educators and advocate unguided learning.
\end{abstract}

Keywords: student-centred learning, pedagogy of extremism, problem-based learning, unifying pedagogy, beside, translation theory

\section{Introduction}

Thus sects arise: schools of opinion. Each selects that set of conditions that appeals to it; and then erects them into a complete and independent truth, instead of treating them as a factor in a problem, needing adjustment. (John Dewey, The Child and The Curriculum, 1902)

We approach the writing of this paper as teachers committed to the emancipation of pedagogy from extremist methodologies of student-centred learning. We argue that the teacher's voice must break through and be heard amidst the silence in the literature of student-centred pedagogy such as problem-based learning (PBL). In the corpus of literature focusing on student-centred learning, it is disturbing that the "I" of the teacher weakly punctuates the critical spaces of education. The forceful approbation for student-centred pedagogy has enabled (or disabled?) the empowerment of student voices but muted the embodied presence of the teacher. As Michel Foucault (1977) reminds us, "the body is also directly involved in a political field; power relations have an immediate hold on it; they invest it, mark it, train it, torture it, force it to carry out tasks to perform ceremonies, to emit signs" (p. 25). To investigate, discuss, examine or critique pedagogy without involving the narrative of a teacher's corporeal experiences is to ignore power-relations that censors and binds our actions and thoughts in the institution. The Foucauldian caution is to avoid the metonymic construction of the teacher as a vessel that can be mechanically used for the implementation of school curricula, standards, policy, and social norms.

Our aspirations for transgressive and powerful scholarship to articulate the unknown, the absent, the "not yet" (Kirylo and Thirumurthy, 2009) within the domains of pedagogy get choked when institutional extremism denounces all other pedagogical approaches except the few. We taught in an institution of higher learning (anonymously referred to as PBL institution) that zealously promoted problem-based learning as the sole methodology of curricular delivery. Advocates of student-centred learning criticise the role of teachers in teacher-centred learning environments with inimical labels such as the "sage on the stage" (Gibson, 1996) and "oracle" (Wiesenberg and Hutton, 1996) of teaching and learning. However, we must ask if the majority of teachers have ever professed to their students that they are omniscient? And if teachers do boldly show their authority and understanding in their field of knowledge, should they be condemned to Jane Gallop's (1982) aggressive metaphors of the phallic teacher and the passive-student receptacle? Kirschner, Sweller and Clarke 
(2006) asserts and base their careful analysis on research evidences that shows that minimal or no teacher guided instructional approaches such as problem-based learning, discovery-based learning and other variants ignore the framework of human cognitive structures that facilitates learning. In their article they convincingly present evidences based upon human-cognitive structures, expert-novices differences and cognitive load, which demonstrates the learning excellence of teacher directed guidance in presenting essential information to students. Needless to say, educational literature is replete with too many dichotomies and borders; conflicting and arbitrary assertions of the "instructivist" versus "constructivist" debates, or teacher-based versus student-centred learning approaches. Scholarship on student-centred learning such as problem-based learning seems to proffer absolute, teleological truths of what we should and must do as educators but the voices, perspectives and experiences of those teaching PBL seem to have been drowned in this intellectual maelstrom.

\section{Underpinning Rationale \& Approach}

The underpinning reason to write this article is to critique the educational practice surrounding problem-based learning that we encountered while working for PBL institution. In the centre of this discord are the demands and instructions of problem-based learning that has effaced the role of a teacher in favour of that of a facilitator. Our contention is not with problem-based learning or any other student-oriented pedagogy but rather with the extremism of educational practice that believes one methodology is superior over all others. Proponents of such an outlook claim that if one is not student-centred then one must surely be the antagonist of student empowerment and self-reflexive learning. This false construction of teaching and learning dynamics creates chasms in education that cannot be crossed because the implementation of $a$ particular pedagogy supersedes all other considerations pertaining to a fluid and dynamic teaching and learning environment. This paper will invoke Eve Kosofsky Sedgwick's conceptual use of beside and the theory of translation to ward against any fundamental advocacy for a particular pedagogy that acts to asphyxiate the capacities and freedom of teaching/learning bodies in education.

We are also invoking our own self-reflexive voices and narratives as a key methodology to critique problem-based learning because the dissenting voices of educators in student-centred learning environments are seldom heard, and often never articulated through the narratives of the self. When feminists claim that the personal is political, it is also a claimant for the power of self-narrative that shapes not only our identity but also the political constitution of others who can verify and attest to the verity of our stories. For Jerome Bruner (1991), all identity construction requires the explication of memory, affective states, self-exposure, self-reflexivity, story telling and an understanding that the only governing convention of narrative is its quest to achieve "verisimilitude" (p. 4). He further explains that truth-values and truth-claims do not exist in the objective world as an object is in space; rather, they are effects of a "hermeneutic composability" that uses narratives to compose subjective truths that define our being-in-the-world (p. 8) When self-narratives are invoked in educational research, the epistemological condition rests firmly on our embodied relation to education. This means, in its simplest and most profound sense, that our lives matter and the weaving of our narratives of oppression, depression, anxiety or hope is the methodological approach to create a community and to understand the system of affective experiences in education. Carol Mullen (1997) clearly explains the emancipatory power of narrative:

Our field borrows from scientific enquiry to produce the idea that any mode of inquiry is to be accompanied by a set of procedures, techniques and plans for achieving an end. For me, this constitutes an image of authority that constricts possibility. Our habitual practice requires us to think that the more systematic our enquiries are, the more vital will be our stories of practice. We complete the circle of incarceration in our academic lives if we allow unexamined perspectives and practices to continue. This shackles us (p. 128).

The importance of Mullen's research on the academe of prisons is in her self-reflexivity, which exposes the insufficiency of studying the narratives of others while failing to articulate one's own voice within a teaching and learning environment. Her work attests to Heljä Robinson's (1994) expression of self-empowerment that defines one's personal narratives as "a valuable contribution... each has a unique voice that echoes the unique experiences of the individual and joins in the voices of others" (p. 159). The expression of one's affective states and memories, or the visceral pain, excitement, frustration, and elation of our being as teachers in an education environment determines the phenomenological value of narratives in pedagogical research. The embodied memories that we share guide our future decisions and, more importantly, problematics of pedagogical practices uncovered in our self-reflexivity creates a collective remembering and politics of action. The unique voices of identities - the teacher, educator, and facilitator - are discursive products of our environment where social structure and individual agency interdependently shapes teaching and learning bodies in education (Waller, 
2010). We are, therefore, echoing the challenge of Christine Halse (2010), a Professor of Education in the University of Western Sydney, who confronts education research to place the narrative experiences of the self within the echelon of acceptable research methodologies. As she clearly notes,

I continue to be surprised by how underutilised life history is as a research method, a framework for analysis, and a narrative strategy for communicating research findings... In Australia, as elsewhere, there persists a (strong) preference for predictable and conventional research methods... Rarely is life history used as a strategy for exploring, understanding and addressing critical issues that impact on education policy and practice (p. 26)

In the epistemological lineage of student-centred learning, especially in problem-based learning, it is rare to hear the dissenting voices of PBL practitioners. Thus the dearth of literature in the oppositional spectrum of PBL research has enabled educational institutions who are caught up in the buzz of student-centred learning to exercise a rigid policy disfavouring the diversity of teaching and learning methodologies. There is, without a doubt, a significant literature on problem-based learning that attests to the strength, validity and reliability of its pedagogical methodology. However, our experiences working in PBL institution has shown that the lack of critique against the limitations of problem-based learning problematises any form of critique or argument against PBL pedagogy.

When the self finds itself in a cul-de-sac of political and intellectual space, the "I" of the pedagogue needs to assert himself/herself by voicing legitimate experiential concerns or else surrender and assimilate into the institution. The vocalisation of life experiences must be articulated through what Theodorea Regina Berry (2010) calls an "engaged pedagogy" so that the texture and resonance of our resistance must engage with our own vulnerabilities that can only be articulated by the "I" of our sensual and perceptive bodies. The primary tenet of embodiment philosophy requires that we do not separate language from the lived body of the subject. The aspirations of the "I" cannot be expressed unless that expression comes from the understanding that our bodies must speak it. Merleau-Ponty (1964) makes the literal point that "to know what language is, it is necessary first of all to speak... It is necessary to take them over, to live them, to speak them" (p. 83). Thus the embodiment of an educator is, first and foremost, the articulation of being a teacher.

In the following sections, we will explicate the observations of the self through speaking about our interactions and experiences within an extremist pedagogical environment. We will explain, with the support of other dissident voices, the problematics of student-centred learning particularly in the context of problem-based learning. It is also our fundamental hope that this article will open a virtual dialogue amongst practitioners of student-centred learning and to engage with our experiences so that we form a critical gulf against any pedagogical extremity. This paper explicates the experiences of two PBL teachers in a tertiary institution but the problematics we encountered are not isolated to our world. Educators such as Alan Neville (1999), in his personal practice as a facilitator in McMaster University, reflects upon and questions the exclusion of the tutor's embodied expression in favour of the student's voice; Doris Santoro Gomez (2008) explores and explicates the illusionary binary that splits the teacher-student into a margin-centre schema; and Francis Maher (2001), in her feminist critique of student-centred learning, questions the blind-sightedness of facilitation when confronted by unequal gender power relations in the classroom. But their personal narratives are eclipsed by their scholarly theories and discourses of exclusion. This is not to say that we, in any way, insist that authors should provide personal accounts of their educational experiences but we are highlighting the dearth and silence of dissenting, personal life narratives, in situations of pedagogical extremism. It is our desire to encourage dynamic scholarship that provides more inclusive research that blends the private, unarticulated self with rigorous, scholarly interventions.

\section{Institutional Background and the "I" in the Pedagogical Maelstrom}

PBL institution is a relatively young school, having been in operation in Southeast Asia for less than 10 years. The institution adopts problem-based pedagogy for all its modules and courses and discourages all other teaching and learning methodologies.

We were hired as full-time academic staff and facilitators for some of the modules being taught in this institution. Initially, we were enthusiastic about being able to work in a PBL environment since it offered a wholesome promise of engaging students in independent and meaningful learning. During the first two weeks of our orientation as facilitators, many newly recruited staff members expressed concern against the evangelical zeal with which problem-based learning was promoted and the rigidity with which it was enforced within the institutional context. In précis, and as paradoxical as it might seem, we were initiated into the ethos of problem-based learning in a didactic and procedural manner, which runs counter to the philosophical groundings 
of problem-based learning that emphasises critical thinking and flexible learning. The institution demanded reflexive students but advocated unreflexive teaching methodologies (Neville, 1999); it demanded critical thinking of students but does not provide the foundation for the acquisition of knowledge (Hannafin and Land, 2000); it prided itself in student-centred learning but failed to understand the feelings and needs of students (and teachers) in learning (Gómez, 2007). The one sticking point in the entire orientation course was the systematic production of a mechanical and robotic facilitator who followed a strict protocol with uncompromising teaching practices involving only problems, worksheets and questions, which we were told should never be answered by the facilitator. This was in contradiction with the principle of flexible teaching that apparently underpins problem-based learning where teaching is customised to meet the varying needs of learners. Frances Maher (2001) offers a poignant example of the frustrations of a facilitator who is trapped rather than empowered from functioning in a problem-based learning environment. She asks, "Why have I often felt so powerless in my own teaching career, caught between things that students said or did that I thought were wrong, even harmful, and the idea that I should always be 'facilitative' and democratic?"' (p. 14). We ask a few exigent questions of our own: Why is teaching and learning dichotomised to the binary paradigms of "traditional" pedagogy versus student-centred learning? Why should the pedagogical approach a teacher adopts be categorized as strictly belonging to either one of the paradigms only? When did educational research arbitrarily split the teacher and student into two distinct beings and identities? What discriminatory scholarship are we proposing in education that would bifurcate teaching and learning as oppositional bastions of thought and practice? And an even more worrying question asks why the dynamic expression of teacher identity is denounced in favour of only a narrow definition of a facilitator?

PBL consolidates its strategic place in educational reforms through its disavowal of what is termed as traditional, didactic, directive, instructional, and teacher-centred learning in favour for student-centred, constructivist and self-directed learning. Robert Delisle notes that "the roots of problem-based learning could be traced to the progressive movement, especially to John Dewey's belief that teachers should teach by appealing to students' natural instincts to investigate and create" $(1997$, p. 1). The method of PBL utilises ill-defined problems (Simon, 1978) even though Dewey's interest was for the advancement of children's metacognitive ability through well-defined problems (Helle, Tynjala and Olkinura, 2006, p. 290). PBL strengthens its pedagogical position by fostering the learning of problems because they must meet "real life" situations and scenarios so that students are prepared for the "real" world of vocations (Gijsalaers, 1995). But John Dewey (revered as the par excellence of student-centred learning) outrightly rejects vocationalism as even a possibility for learning. As he states unambiguously:

We must avoid not only limitation of conception of vocation to the occupations where immediately tangible commodities are produced, but also the notion that vocations are distributed in an exclusive way, one and only one to each person. Such restricted specialism is impossible; nothing could be more absurd than to try to educate individuals with an eye to only one line of activity (1926, p. 279)

In the capitalistic world of education where profit rules and professionalism is market approved, it would be contentious if one had an eye to more that one line of specialised, vocational activity. The institution had an unwavering commitment to vocationalism because the stakeholders of the school needed work-worthy students that were given sufficient training and problem-solving skills to enter the workforce. We were taught not to question this agenda since it was based on the pedagogical belief that solving real life problems equated to real-life readiness to face problems (Fenwick and Parson, 1997).

The problems designed in PBL advocate discovery learning. From a theoretical perspective this is a laudable idea. When psychologist Jerome Bruner (1961) expressed that students should be able to discover new ideas for themselves rather than practice mnemonic learning, it spurred an educational impetus to break the stranglehold of power relations that consistently favoured the teacher as an omnipresent being of absolute knowledge. The problem, however, arises when educators favour a puritanist "pure discovery" learning methodology that denounces the concept of explicit teaching as an appropriate means to student learning. Richard Mayer's (2004) discovery of 1950s research conducted on pure versus guided discovery learning shows that those students who are predominantly left on their own to discover knowledge always end-up doing more poorly than students who receive help and information from their teachers. This extremist version of discovery learning was articulated during our training as a facilitator in the institution. We were told that students should never be given a direct answer when trying to solve their problems. If students raised questions, as facilitators we should only guide by providing further questions. If a student should ask us "Why is the sky blue?" our role was to ask the student and others, "What do you think?" or "Why do you think the sky is blue?" or "Are there any other answers to this question?" As Hmelo-Silver, Nagarajan and Derry (2006) confirms, "More experienced facilitators tended to use 
questions that tossed the responsibility for learning back to the students" (p. 76). This "guiding" strategy created further frustrations amongst new staff members when the trainer said that the students should refer only to scholarly work and online research to solve their problems. We were told never to answer their questions with a direct response. We couldn't help but pose the rhetorical question as to why books and scholarly articles written by a scholar were acceptable sources of knowledge, but PBL facilitators were effaced from the fundamental acknowledgement that they too were living bodies of knowledge who may impart wisdom, information, critical thoughts and ideas?

Alan Neville (1999) confirms our experiences when he said that tutors who are placed into a PBL environment feel constrained to act as "wallflowers" in the classroom because their purpose is only to observe the process and tutorial dynamics. We cannot justify Malcolm Knowles' (1975) passionate expression of his experience with problem-based learning when he exclaims that moving from teacher to facilitator "required that I divest myself of the protective shield of an authority figure and expose myself as me - an authentic human being, with feelings, hopes, aspirations, insecurities, worries, strengths and weaknesses" (p. 33). It was disconcerting to realise that a puritanist PBL does not acknowledge the agency of being a facilitator. The facilitator is required to act like the machine in John Searle's Chinese Room Argument. It is rather paradoxical that the idealist PBL environment is meant to empower both the teacher and students as thinking individuals to counter the criticisms levelled against traditional didactic learning environments. However, in the implementation of PBL in the institution, the enforcement of pedagogic rules was done in a very rigid and procedural manner with facilitators being taken to task if they veered from the sanctioned norms. Any form of what was seen to be a provision of knowledge or lecturing was strictly discouraged even when the classroom situation warranted it. Our purpose as educators in the PBL environment seemed designed to merely project scripted and automatic responses to students; creating a façade of a productive and progressive learning environment when in actuality we were conforming to a system of extremist pedagogy.

Problem-based learning, as promoted by the institution, advocated unabashed student-centred learning without critical or sufficient understanding of pedagogical methodologies beyond problem-based discourses. Educational literature is replete with fierce criticism of what is termed as "traditional" pedagogy and PBL positions itself on the diametric opposite of the spectrum of "old-fashioned" educational philosophy and practice. Proponents of purist PBL, such as Sue Baptiste, confidently and worryingly claims, "I became almost evangelical about this newfound lease on learning. I wanted to make sure that others appreciated the delight of it all; that others would become 'converted' was one of my major goals" (2003, p. xiii). Bereiter and Scardamalia (2000) differentiated the "PBL" written in the uppercase and "pbl" written in the lowercase. The former is advocated by the extremists of problem-based learning, which closely adheres to the teaching and learning structure of Howard Barrows $(1985 ; 1986 ; 1994)$. While not many education researchers would claim to be evangelical about PBL even if they do support it, there are proponents of student-centred learning that border towards an uncompromising support and universalisation of pedagogy.

The ultimate fear of any scholar who is committed to critical and transformative pedagogy is "a discourse increasing in circulation and defenders" and as such "PBL wields considerable potential power in determining 'legitimate' knowledge, and in shaping professionals' thinking and intentions" (Fenwick and Parsons, 1997, p. 5). In the school we worked in, this "potential" has turned into an institutional reality that cuts across and is forcibly enforced in every curriculum, faculty and department. Lecturing and/or blended-based learning is strongly discouraged with institutionally sanctioned warnings and punishments. We need specific tactics, philosophical, and pragmatic approaches to break the stranglehold of a solipsistic student-centred education that is fast gaining ground. An aggressive critique of educational puritanism and the pedagogy of extremism must be advanced by a dynamic and translative pedagogy that is holistically unifying and inclusive, thus integrating the elements of both student-centred learning and teacher-directed teaching.

\section{Critiquing the Pedagogy of Extremism}

Beside is an interesting preposition also because there's nothing very dualistic about it; a number of elements may lie alongside one another, though not an affinity of them ... Beside comprises a wide range of desiring, identifying, representing, repelling, paralleling, differentiating, rivalling, leaning, twisting, mimicking, withdrawing, attracting, aggressing, warping, and other relations. (Eve Kosofsky Sedgwick, Touching Feeling, 2003)

The conceptual use of beside has a significant and strategic position in countering the influence of the pedagogy of extremism. The pedagogical enterprise of a critical scholar and educator must not advocate a seamless and teleological progression, which smoothes and corrects any form of contradiction to promote an apodictic truth in 
education. An eclectic and unifying pedagogy must allow the flourishing and co-existence of contradictions. Such a statement does not infer that paradoxes and oppositions should be left unanalysed, uninterrogated or overlaid for the purpose of building a massive tangle of differences. Such a pedagogical intention would in effect abrogate any effective teaching and only produce epistemological confusion. Contradictions are affirmed to acknowledge fields of differences, which may or may not reconcile its disparities but nevertheless opens opportunities to discuss, debate and create divergent plateaus of innovative thoughts and knowledge. Contradictions do not exist in an immediate and direct conflict, but must first be beside its antagonist before any oppositional engagement can ensue. As Gómez (2008) cautions, we must remove ourselves from the margin-centre schema of pedagogy which delineates a territorial centre occupied by students and an outer margin that is the policing boundary of education that teachers must occupy and never trespass. She exclaims, "Certain extreme interpretations of student-centred pedagogy have diminished, if not eradicated, the essential role of teachers as responsive and responsible educators in their classrooms" ( $p$. 316). Thus a hermeneutics of radicalism gives rise to a pedagogy of extremism when scholars and discourses cannot find conciliatory grounds to be adjacent, next-to and beside one another.

A pedagogy of extremism cannot endure being flanked by contradictions and incommensurabilities because its nature is to erect intellectual fortifications that prohibit diversity, differences and plurality. We are reminded of Ien Ang's (1997) intervention to Rita Felski's "doxa of difference". She states that while absolute differences could be impediments to the political empowerment of identities, incommensurabilities should not be undermined as merely obstructions. Incommensurabilities are the residues of the irreducibly particular that cannot, ultimately, be shared' but this does not mean that communication indefinitely breaks down. On the contrary, incommensurability

relates to the occasional and interspersed moments of miscommunication (or breakdown of communication) that always accompany communicative interchanges between differently positioned subjects. Ironically, such moments of incommensurability, while generally not acknowledged as such, are precisely what propel us to go on communicating, forever chasing for an ultimate fullness of understanding and complete commonality that are never achieved (Ang, 1997).

A scholar's drive and commitment to communicate differences gives credence to contradictions not because contradictions are products of insufficient analysis or epistemological confusion that finds no avenue of consensus but rather because incommensurable contradictions are the result of gaps and incomplete knowledge. As such, epistemologies are always imperfect, deficient and inadequate because apodictic truths are never fully realised nor could there be universal, transcendental truths that are unaffected by the constant shift and transformations of material, lived experiences.

The movement of exclusive PBL is unable to accommodate political and philosophical differences in pedagogy. During the period of our working in the institution we felt curtailed in exploring pedagogical strategies alternative to PBL that we thought would have had better impact in improving students' learning. To critique a pedagogy of extremism is to commit to a dialogical relationship between teacher and student, which allows a student to "speak in their own voices" and "draw from their own experiences" that are both socially and culturally distinct (Giroux, 1983). But the entrapment in mis-interpreting such a statement is to myopically accentuate our dedication to student self-directed empowerment while forgetting that a dialogical relationship requires also the fully embodied experience and articulation of the teacher's body and voice in education. One of the many important roles of the teacher is to guide but not from an uncaring and insouciant distance with the occasional lip service to questions that masks as concern for student-directed learning. Kirschner, Sweller and Clark (2006) cautions through their research in human cognitive architecture that minimal guidance in student-centred learning pedagogies does not work. They state "in so far as there is any evidence from controlled studies, it almost uniformly supports direct, strong instructional guidance rather than constructivist-based minimal guidance during the instruction of novice to intermediate learners" (p. 83). Mayer (2004) expresses an equally strong disapproval for unguided teaching through research evidence from the 1950s to the 1980s that explicitly and consistently condemns problem-based learning that favours a wholesale implementation of unguided learning. This critique is food for thought for purist proponents of problem-based learning and should trigger them to review the body of knowledge supporting PBL to analyse if it can be positioned within a more eclectic, unifying and transformative framework of education.

Another vital aspect of this critique against a pedagogy of extremism lies in the lessons and theory of feminism and translation studies. To articulate the angst and frustrations of the disempowered teacher, we must evoke translative, pedagogical tools shaped, historically, by women. Sherry Simon (1996) explains that "translation" and "women" were historically considered the handmaidens of authors. This discursive act to discriminate 
women's position in the hierarchical strata of masculine vocations serves to confine the woman's body within acceptable gender boundaries of the public sphere. Reversing the discourse of translation from the subordinated act of the feminine to a political practice and empowerment of the feminine, however, challenges this inimical position. As Susanne De Lotbiniere-Harwood (1990) states, "My translation practice is a political activity aimed at making language speak for women... to make the feminine visible in language" (p. 9). The discourse of translation is already steeped in defiance, opposition and unfamiliar borders and the primary purpose of translation is to decode, decipher and to interpret an "other" culture. Translation in pedagogical practices is a powerful antidote to a pedagogy of extremism because it must dialectically synthesise two (or sometimes more) contending and dichotomous positions. In education, the embodied language and authority of the teacher and the self-directed impetus of the students' voices occupy these positions.

Pedagogical translation creates complex and conflicting discursive fields in education. The teacher must question how he/she can decipher and express difficult and, at times, dangerous knowledge to the student. The student must translate their desires and difficulties in learning to the hardened ears of their teachers. The curriculum and educational system must translate their policies, ethos, and vision to the people working and studying in the institution. A pedagogy of extremism can only root itself in education when communication breaks-down and translation fails to convey the multiplicity of voices. Barbara Grant (2009) expresses candidly that the relationship between teacher and student is a dialogical and translative process. She argues this through the Hegelian metaphor of master and slave and contends that they are problematic concepts only when we acknowledge that this relationship is immutable, non-transferable, and permanent in their ontological positions. Relationships are meant to be difficult, at times solipsistic, and sometimes passionately indescribable. A translative pedagogy is "an attempt to explore the emergence of human self-consciousness: this process is always accompanied by a struggle for recognition between two consciousness bound together in an ambiguous and contradictory relation of dominance and subordination" (p. 129). In the words of Robert Scholes (2003), we "teach in order to learn" and "we learn in order to teach" (p. 14). The master is sometimes the slave when our students provide us insights into a culture beyond our own or exercise their hermeneutic perspectives that trigger us as teachers to recalibrate our theoretical views. The slave is never shackled to dominance especially when we err in our duties. The student exercises the right to justice when we have marked them unfairly and sometimes because we grade too sympathetically. We are, and will always be, master and slave. Our dialogical relationship shows that translative practices in education must bridge cultures, people, perception and knowledge and to do so we can never simply and absurdly utilise one methodology or a singular pedagogical strategy. The pedagogy of extremism cannot accommodate difference or contradictory methods of instruction and seeks to impose the sole supremacy of its chosen pedagogical orientation in the classroom. Tara Fenwick and Jim Parsons' prophecy about PBL rings true. The facilitator is not only removed from the public, "both liability and responsibility of reparation and sharing in the world's suffering, but also perpetuates the comfortable illusion that prediction and control are possible" (1997, p. 9). The consequence of this prediction is the disenfranchisement of students' learning and as Michael Hannafin and Susan Land (2000) observes, learners in problem-based learning begin to "draw upon unstable or inaccurate knowledge to organise new knowledge, they may paradoxically strengthen sophisticated misunderstandings that are both robust and difficult to alter" (p. 15).

\section{An Alternative to the Pedagogy of Extremism: A Unifying and Eclectic Pedagogy}

It should be highlighted that, initially, both the authors of this paper were positively favourable towards the teaching of curricular subjects using PBL as the sole methodology of instruction, particularly with the second author having authored journal publications on the merits of PBL. With growing experiences as educational researchers and practitioners, the authors have had to re-think over their positions in this regard. Our disillusionment rests not with PBL or for that matter any other alternative student-centric approaches but rather in the application of any one of these approaches as the sole and supreme educational methodology. Our criticism lies with a pedagogy of extremism where student-centred learning advocates and eulogize one pedagogical method that they might have arbitrarily or conveniently chosen as the sole panacea for all educational ills and vilify all other practices, especially those that might be teacher-centric in orientation. We argue that what is needed is a more balanced and inclusive conceptualization of pedagogy or unifying pedagogy as we choose to call it - an approach where both student and teacher voices are heard and are given legitimate spaces to interact with one another to shape classroom educational discourses.

The polemics of PBL are metonymic of the pedagogical merits and limitations of instructivist and constructivist instructional models that have been the focus of much debate and arguments in educational circles. Traditionalists from the instructivist school of educational thought insist that constructivist modes of learning (underpinned by critical thinking and collaborative discourse) are too unstructured, unregulated, open-ended and 
contentious. On the other hand, constructivists counter-argue that traditional formats of instruction are untenable since they are too rigid, didactic, teacher-driven and passive. The argument is that traditional pedagogy is unable to infuse in students' divergent, higher-order thinking skills, which are necessary for them to function effectively in real-world working contexts. If we situate these two epistemological models on a scale, they will form the extreme ends of an extended continuum. And the nature of extremity is to stretch itself further and further away from its opponent; it is antithetical to compromise, against being epistemologically or phenomenologically beside one another, and have no cause to translate the material lived experiences of those who work in the shadow of extremism. We posit that unifying pedagogy, with its inclusive blend of instructivist and constructivist principles of learning, will fall within the middle strata of such a continuum. This is based upon the argument that unifying pedagogy strikes the fine balance between the needs for teacher and student control an issue of heated disagreement amongst educational theorists and practitioners on determining the extent to which each type of control needs to be exercised in order to optimize the learning potential of students. In a unifying pedagogical environment, cognitive opportunities for students to be independently and actively engaged in their learning (i.e fostering student-centred learning) are richly provided but the framework of instruction is also teacher-driven (curricular scope and content are framed by teachers). The goal of unifying pedagogy is to give ample space for hearing both students' and teachers' voices in classroom interactions. The purpose is to stimulate what Dewey (1938/1997) eloquently describes as positive educative experiences - "a positive educative experience arouses curiosity, strengthens initiatives, sets up desires and purposes that are sufficiently intense to carry a person over a dead place in the future" (p. 38). We believe that unifying pedagogy, when judiciously applied, takes into consideration the students' unique learning needs which allows for the teacher to explicitly teach/lecture where necessary, provide expository information where needed and contiguously offer ample opportunities for students to independently engage in knowledge construction, peer collaboration and meaning making. Such a pedagogical approach is not only a sustainable and scalable curricular model but also promises the attainment of Dewey's positive educative experiences.

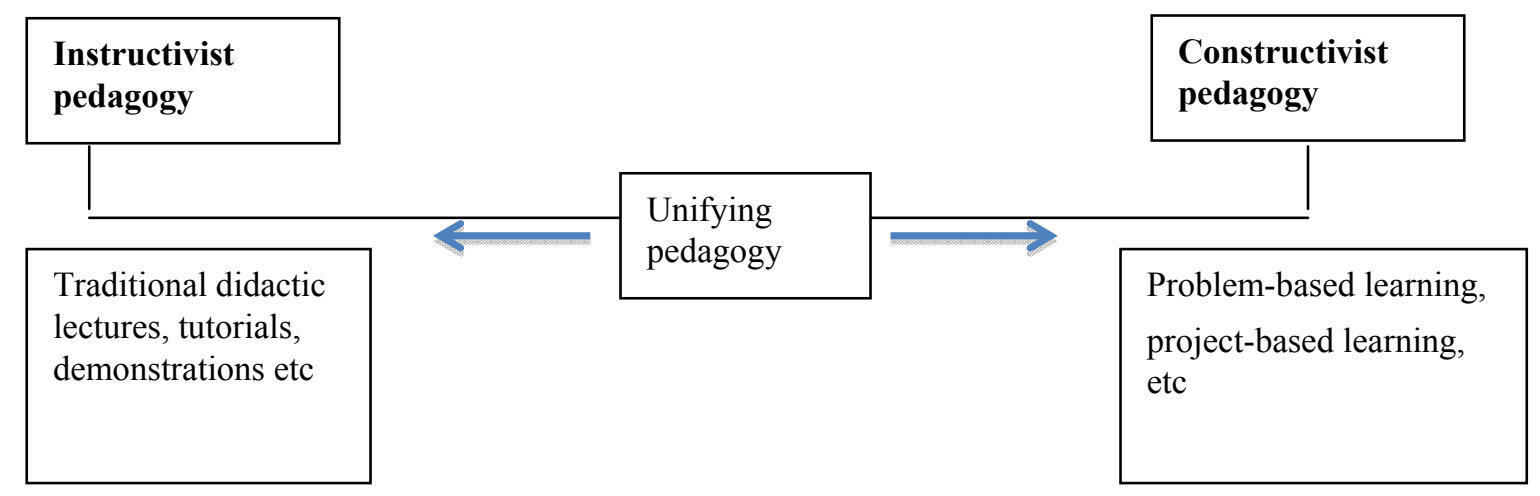

Figure 1.

\section{Conclusion}

There has been a flurry of new names and titles for student-centred, constructivist learning such as inquiry-based learning, project-based learning, challenge-based learning (Baloian et. al., 2006), blended problem-based learning (Woltering, Herrler, Spitzer, Spreckelsen 2009), reform-based teaching (Barak and Shakhman, 2007), SCLEs or student-centred learning environments (Hannafin and Land, 2000). As scholars, teachers and learners, we should have no quarrel with the continual expansion and development of education into divergent and expressive pathways. In fact, we should embrace the multifaceted prism of pedagogical methods and strategies so as to always and continually forge fluid and dynamic ways of teaching our students and ourselves. We must never, however, produce and support a cultish view of pedagogy that unconditionally gives credence to only one teaching and learning strategy. Ironically (or tautologically), it is the ardent desire of a group of scholars to unreservedly implement a pedagogical method that creates a deadly catalyst to silence both teacher and student desires in learning.

An emancipatory education is neither PBL nor is it "traditional" teaching. Insofar as the learning environment is constantly shifting, unpredictable and mediated by the complex vacillation of student and teacher desires transformed by cultural values, racial differences, gender hegemony, sexual prejudices and class hierarchies, we must think of an unifying pedagogy that utilises what it must and could within specific environments. There are 
no centres or margins in education; there are only embodied expressions of learning, desire and scholarship besides a multitudinal and distributed network of bodies, epistemologies and ontologies. An exigent call has been made in this paper for an eclectic and unifying pedagogy that must be flexible enough for teachers to manoeuvre through dense intellectual terrains with the critical thoughts and actions of students. It is imperative that educators and researchers are beside the multifaceted technologies and techniques of teaching and learning in the classroom so that we do not become myopic and blinkered to a one-size-fits-all educational solution. Our scholarship should no longer valorise for a singular pedagogy but ask, as we all must, for the translation of teaching and learning strategies for the most effectual teacher-student educational scholarship. We must "experience" as Dewey writes, to "articulate the inclusive, multi-faceted, that is to say fully human, modes of apprehending, reacting to, and interacting with our surrounding" (Boisvert, 1998, p. 14). To do so, we must also dedicate and commit ourselves fully, and always, against the exclusivity of a pedagogy of extremism.

\section{References}

Ang, I. (1997). Comments on Felski's "The doxa of difference": The uses of incommensurability. Signs, 23(1), 57-65. Retrieved from Infotrac http://0-web4.infotrac.galegroup.com.prospero.murdoch.edu.au/itw/infomark/244/344/60006218w4/purl=rc 1_EAIM_0_A20402537\&dyn=7!ar_fmt?sw_aep=murdoch

Baloian, N., Hoeksema, K., Hoppe, U., \& Milrad, M. (2006). Technologies and educational activities for supporting and implementing challenge-based learning. In D. Kumar and J. Turner (Eds.). Education for the 21st century: Impact of ICT and digital resources (pp. 7-16). http://dx.doi.org/10.1007/978-0-387-34731-8_2

Baptiste, S. (2003). Understanding problem-based learning: A self-directed journey. Thorofare: Slack Publications.

Barak, M., \& Shakhman, L. (2008). Reform-based science teaching: Teacher's instructional practices and conceptions. Eurasia Journal of Mathematics, Science and Technology Education, 4(1), 11-20.

Barrows, H. (1985). How to design a problem-based curriculum for pre-clinical years. New York: Springer Publishing Co.

Barrows, H. (1988). The tutorial process. Springfield, IL: SIU School of Medicine.

Barrows, H. (1994). Practice-based learning: Problem-based learning applied to medical education. Springfield, IL: SIU School of Medicine.

Barrows, H. S., Myers, A. C. Williams, R. G., \& Moticka, E. J. (1986). Large group problem-based learning: A possible solution for the "2 sigma problem. Medical Teacher, 8(4), 325-31. http://dx.doi.org/10.3109/01421598609028991

Bereiter, C., \& Scardamalia, M. (2000). Process and product in problem-based learning. In D.H. Evensen, C.E. Hmelo and C.E. Hmelo-Silver (Eds.). Problem-based learning: A research perspective on learning interactions (pp. 185-196). Mahwah: Lawrence and Erlbaum Associates.

Berry, T. G. (2010). Engaged pedagogy and critical race feminism. Educational Foundations, Summer-Fall, pp. 19-26.

Boisvert, R. D. (1998). John Dewey: Rethinking our time. New York: State University of New York Press.

Bruner, J. S. (1991). The Narrative Construction of Reality. Critical inquiry, 18(1), 1-21. http://dx.doi.org/10.1086/448619

Bruner, J. T. (1961). The act of discovery. Harvard Educational Review, 31, 21-32.

Delisle, R. (1997). How to use Problem-based Learning in the Classroom. Virginia: Association for Supervision and Curriculum Development.

Dewey, J. (1929). Democracy and Education: An Introduction to the Philosophy of Education. Raleigh, NC: Hayes Barton Press.

Dewey, J. (1938/1997). Experience and education. New York: Simon \& Schuster.

Fenwick, T. J., \& Parsons, J. (1997). A critical investigation of the problems with problem-based learning. (Research Report No. 143) U. S. Department of Education, (ERIC Document Reproduction No. ED409 272).

Foucault, M. (1977). Discipline and punish: The birth of the prison. (A . Sheridan, Trans.). New York: Vintage. 
Foucault, M. (1998). The history of sexuality vol. 1: The will to knowledge. London: Penguin. (Originally published 1976).

Gallop, J. (1982). The immoral teachers. Yale French studies: The pedagogical imperative: Teaching as a literary genre, 63, 117-128.

Gibson, C. C. (1994). Toward emerging technologies and distributed learning: Challenges and change. American Journal of Distance Education, 6, 47-49.

Giroux, H. A. (1983). Theory and resistance in education: A pedagogy for the opposition. Massachusetts: Bergin and Garvey Publishers.

Gómez, D. S. (2008). Women's proper place and student-centred pedagogy. Studies in Philosophy and Education, 27, 313-333. http://dx.doi.org/10.1007/s11217-007-9048-0

Grant, B. (July, 2009). Uneasy translations: Taking theories of supervision into teaching. London Review of Education, 7(2), 125-134. http://dx.doi.org/10.1080/14748460902990385

Halse, C. (2010). A Process of (Un)becoming. In P. Harnett (Ed.), Exploring learning, identity and power through life history and narrative (pp. 25-38). New York: Routledge.

Hannafin, M., \& Land, S. (2000). Technology and student-centered learning in higher education: Issues and practices. Journal of Computing in Higher Education, 12(1), 3-30. http://dx.doi.org/10.1007/BF03032712

Helle, L., Tynjala, P., \& Olkinuora, E. (2006). Project-based learning in post-secondary education - theory, practice and rubber sling shots. Higher Education, 51, 287-314. http://dx.doi.org/10.1007/s10734-004-6386-5

Hmelo-Silver, C. E., Nagarajan, A., \& Derry, S. (2006). From face-to-face to online participation: tensions in facilitating problem-based learning. In M. Savin-Barden and K. Wilkie (Eds.). Problem-based learning online (pp. 61-78). Buckingham: Open University Press.

Knowles, M. S. (1975). Self-directed learning. New York: Harper and Row.

Lampert, M. (2001). Teaching problems and the problems of teaching. New Haven, CT: Yale University Press.

Lotbiniere-Harwood, S. (1990). Introduction: Proust's grandmother and one nights: The 'cultural turn' in translation studies. In S. Bassnett and A. Lefevere (Eds.). Translation, history and culture (pp. 1-13). New York: Cassell.

Maher, F. (2001). John Dewey, progressive education, and feminist pedagogies: Issues in gender and authority. In K. Weiler (Ed.), Feminist engagements: Reading, resisting, and revisioning male theorists in education and cultural studies (pp. 13-32). New York: Routledge.

Mayer, R. E. (2004). Should there be a three-strikes rule against pure discovery learning? The case for guided methods of instruction. American Psychologist, 59(1), 14-19. http://dx.doi.org/10.1037/0003-066X.59.1.14

Merleau-Ponty, M. (1964). The primacy of perception. Illinois: Northwestern University Press.

Mullen, C. A. (1997). Imprisoned selves: An inquiry into prisons and academe. Maryland: University Press America.

Neville, A. J. (1999). The problem-based learning tutor: Teacher? Facilitator? Evaluator? Medical Teacher, 21(4), 393-401. http://dx.doi.org/10.1080/01421599979338

Robinson, H. A. (1994). The ethnography of empowerment: The transformative power of classroom interaction. London: Falmer Press.

Scholes, R. (Spring 2003). Learning and teaching. ADE Bulletin, 11-16.

Sedgwick, E. K. (2003). Touching feeling: Affect, pedagogy, performativity. Durham and London: Duke University Press.

Simon, H. A. (1978). Information processing theory of human problem solving. In W. K. Estes (Ed.), Handbook of learning and cognitive processes (pp. 271-295). Hillsdale: Lawrence Erlbaum Associates, Inc.

Waller, R. (2010). Changing identities through re-engagement with education. In P. Harnett (Ed.), Exploring learning, identity and power through life history and narrative (pp. 55-69). New York: Routledge.

Wiesenberg, F., \& Hutton, S. (1996). Teaching a graduate program using computer-mediated conferencing software. Journal of Distance Education, 11, 83-100. 
Wilkie, K. (2000). The nature of problem-based learning. In S. Glen, \& K. Wilkie (Eds.). Problem-based learning in nursing: A new model for a new context? (pp.11-36). Hampshire and London: Macmillan Press.

Woltering, V., Herrler, A., Spitzer, K., \& Spreckelsen, C. (2009). Blended learning positively affects students' satisfaction and the role of the tutor in the problem-based learning process: results of a mixed-method evaluation. Advance Health Science Education Theory Practice, 14(5), 725-738. http://dx.doi.org/10.1007/s10459-009-9154-6 